\title{
The English 'Open Field' System
}

The Open Fields

By C. S. and C. S. Orwin. Pp. xii $+332+29$ plates. (Oxford: Clarendon Press; London: Oxford University Press, 1938.) 21s. net.

$\mathrm{T}$ HE layout of the countryside of England as we see it to-day is a very recent development ; even the strict four-course rotation that in many places preceded it, and which is often regarded as the real old English system of farming, lasted but little more than a century. The system that had the long life in England was the one associated with the open fields. It comprised two distinct features: sub-division of the land among those entitled to share in it; and a rotation which usually consisted of winter corn : spring corn : fallow : it is thus described by Tusser in 1573 :

First rie and then barlie the champion saies Or wheat before barlie be champion waies :

But drinke before bread corn with Middlesex men,

Then lay on more compas, and fallow agen.

Although the land was very much sub-divided, the cropping appears to have been usually consolidated, and the total area of arable land of the village was set out in three fields, each devoted wholly to one part of the rotation. Each field was divided into small areas which were allocated to those entitled to receive them, but each man's holding was scattered over all three fields : each could, therefore, in principle, receive his share of good and of poor soil. The land was left open, unenclosed by hedges: the system is therefore called the 'open field system' and the process of bringing it to an end was called 'enclosure'.

Mr. and Mrs. Orwin have rendered splendid service to all interested in the history of the countryside by drawing up a full and detailed account of the working of the system in the ancient Nottinghamshire village of Laxton, of which, fortunately, unusually full records have been preserved and where, indeed, part of the system still survives. Their book thus becomes valuable source material; and the copious extracts from the old documents, and a complete transcription of the "Booke of Survaye" of 1635, give it unusual value for those who wish to acquire more than the usual sketchy knowledge of the subject.

Experts will be particularly grateful for the useful account of the management of grazing for livestock under this system. Grazing was, of course, very inadequate, and much slaughtering and salting down had to be done round about Michaelmas, because there would be no food for the animals during winter : to quote Tusser again :
At Hallowtide, slaughter time entereth in, And then doth the husbandman's feasting begin : From thence unto Shroftide kill now and then some, This offal for houshold the better wil come.

But it was always obvious that some provision had to be made for what farmers call 'winter keep', and the authors show how this was done.

The extensive quotations from the records of fines throw valuable light on the agricultural and general life of the village : indeed the whole range of country life in England in the seventeenth century is illuminated by the well-chosen extracts.

The origin of the system is still obscure. Part of the system, the sub-division of the land and the scattering of the holdings, was widely spread around the Baltic; it is still in use in Poland; it has not long been displaced in Russia; also it is still practised in Northern India. The rotations also showed some resemblances to those used in England, but consolidation of cropping was not so common, and is not usual either in Poland or Northern India, except where some special circumstance has necessitated its adoption.

The system had the advantage of permanence, and there is no evidence of soil deterioration throughout all the years that it was practised. Also it accorded with the peasants' fundamental rule of husbandry, 'safety first' : for if the crop on one of his strips was bad there was always the possibility that the yield on another might be better. But it had the grave disadvantage that yields were low and improvements extremely difficult: only when the scattered holdings were brought together into one piece could better methods be used. In England this process of consolidation began in Tudor times, and was continued almost to our own day. In Russia it was achieved after the Revolution under the name 'collectivization': in Poland, France (where necessary) and India it goes on more gradually and by persuasion.

The system can find no place in modern country life. It belongs to the old village life : the days of the craftsman, of folk dances and folk songs, of the old feasts and fairs, but it has passed. One cannot regret it, because it could not produce food in sufficient quantity or variety to maintain the village population in health. But it has left its mark deeply on the countryside: indeed the plan of the village to-day is frequently in the main lines almost the same as when the system was in operation.

E. J. RusSELL. 